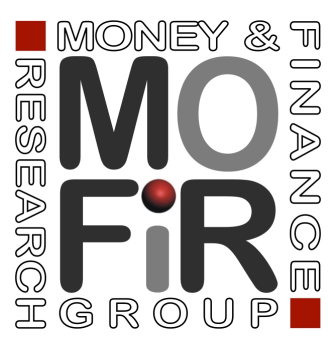

FINANCIAL SHOCKS, BANKRUPTCY, AND NATURAL SELECTION

Hirofumi Uchida Daisuke Miyakawa Kaoru Hosono Arito Ono Taisuke Uchino Iichiro Uesugi

Working paper no. 110

July 2015 


\title{
Financial Shocks, Bankruptcy, and Natural Selection ${ }^{\dagger}$
}

July 2015

\author{
Hirofumi Uchida (Kobe University) ${ }^{\ddagger}$ \\ Daisuke Miyakawa (Hitotsubashi University) \\ Kaoru Hosono (Gakushuin University) \\ Arito Ono (Chuo University) \\ Taisuke Uchino (Daito Bunka University / RIETI) \\ Iichiro Uesugi (Hitotsubashi University / RIETI)
}

\begin{abstract}
${ }^{\dagger}$ This study is the result of the Study group for Earthquake and Enterprise Dynamics (SEEDs), which participates in the project "Design of Interfirm Networks to Achieve Sustainable Economic Growth" under the program for Promoting Social Science Research Aimed at Solutions of Near-Future Problems and the Social Scientific Survey of the Great East Japan Earthquake conducted by the Japan Society for the Promotion of Science (JSPS) and the Project on Corporate Finance and Firm Dynamics undertaken at the Research Institute of Economy and Trade and Industry (RIETI). An earlier version of this paper was presented at the USC-Gakushuin conferences on "The Economic Impact of the Supply Chain Disruptions in the Great East-Japan Earthquake,” at the Fall 2013 meeting of the Japanese Economic Association at Nagoya City University, and the Workshop on the Economic Effects of the Great Tohoku Earthquake at RIETI. The authors want to thank Makoto Hazama for his superb research assistance; the two anonymous referees, Yasushi Hamao (our editor), Jonathan Eaton, Theresa Greaney, Tetsuya Misawa, Makoto Nirei, Etsuro Shioji, Miho Takizawa, Hideki Toya, Kazuki Yokoyama, Katheryn Russ, Eric Weese, Tsutomu Miyagawa, and Robert Dekle for their helpful comments; Hitotsubashi University for financial support; and to Teikoku Databank, Ltd. for providing the data. We gratefully acknowledge financial support from Grant-in-Aid for Scientific Research (S) No. 25220502, and K. Hosono and H. Uchida respectively acknowledge support from Grant-in-Aid for Scientific Research (S) 22223004 and (B) No. 22330096, all from JSPS.

¥ Graduate School of Business Administration, Kobe University, 2-1 Rokkodai, Nada, Kobe 657-8510, Japan. Tel.\&Fax.: 81-78-803-6949, E-mail: uchida@ b.kobe-u.ac.jp.
\end{abstract}




\title{
Financial Shocks, Bankruptcy, and Natural Selection
}

\begin{abstract}
In this paper, we investigate whether financial shocks to firms affect their probability of bankruptcy. We also examine whether these shocks affect the natural selection of the firms, whereby more efficient firms are less likely to go bankrupt. By using the data on the bankruptcy of firms after the Great Tohoku Earthquake, we examine the impact of the damage to lender banks on the firms’ probability of bankruptcy. To extract the impact of purely exogenous financial shocks on bankruptcy, we focus on firms located outside the earthquake-affected area but that transact with banks located inside the area. Our findings somewhat counterintuitively suggest that a damaged bank reduces the probability of bankruptcy and weakens the natural selection of firms. We further examine the impact of the injection of public capital into damaged banks and obtain some evidence that the injection reduces the probability of the bankruptcy of their borrowers and weakens the natural selection.
\end{abstract}

Keywords: firm bankruptcy, natural selection, natural disaster, capital injection, financial constraint JEL classification codes: L10, G21 


\section{Introduction}

Do financial shocks affect the real activities of the corporate sector in an economy? Numerous studies have tried to answer this question by focusing on the adverse shocks transmitted by the banks that the firms transact with. This focus reflects the fact that for many firms, especially smalland medium-sized enterprises (SMEs), one of their key sources of finance is loans from banks. Such studies investigate whether the shocks from these banks have a real impact on the different aspects of corporate activities, for example, capital investment (Hosono et al. 2012; Amiti and Weinstein 2013), exports (Amiti and Weinstein 2011; Paravisini et al. 2011; Miyakawa et al. 2014), and construction activities (Peek and Rosengren 2000). In this paper, we focus on the impact of the financial shocks on an important aspect of a firm’s dynamics: bankruptcy.

The major challenge to this examination is how to overcome the endogeneity problem. While the shock to banks could adversely affect the real activities of the borrowing firms, the poor performance of the borrowers could also adversely affect the performance of the banks. Thus, it is difficult to empirically identify the direction of the causality. There are some approaches to address this problem. We follow the approach that takes advantage of a financial shock that is purely exogenous to the firms. To be precise, we use the data on the bankruptcy of firms after the Great Tohoku Earthquake (also known as the Great East-Japan Earthquake) that hit the Tohoku area of Japan on March 11, 2011. ${ }^{1}$ We focus on the impact of the damage that the firms' main banks suffered from the earthquake. Because main banks are the primary source of finance for SMEs in Japan, damage to them can cause a serious financial shock to the borrowers.

1 There were 27,154 casualties (18,131 dead, 2,829 missing, and 6,194 injured) due to this earthquake, the accompanying tsunami, and the accident at the nuclear plant in Fukushima (Fire and Disaster Management Agency of the Government of Japan: http://www.fdma.go.jp/ bn/higaihou/pdf/jishin/146.pdf (in Japanese)). 
Although we can naturally expect that the damage to the banks has an adverse impact on the banks' lending capacity, the poor performance (in our case, bankruptcy) of the firms located inside the affected area might reflect their own damage from the earthquake as well. To alleviate this problem, we use the data on SMEs that are located outside the earthquake-affected area to extract a purely exogenous shock from the financial frictions with the damaged banks. ${ }^{2}$ We examine the differences in their probability of bankruptcy based on whether their banks did or did not suffer damages from the earthquake. To represent a bank’s damage, we use two proxies: the location of the banks' headquarters inside the affected area and the share of their branch offices inside the affected area.

In addition to this investigation, we are also interested in whether and how the financial shock changes the natural selection of the firms, that is, the mechanism through which the market eliminates inefficient firms (e.g., Bertin et al. 1996, Bresnahan and Raff 1991, Caballero and Hammour 1994, 1996, 2005). While the evidence in the literature suggests that natural selection indeed works after the Great Tohoku Earthquake both inside and outside the affected area (e.g., Uchida et al. 2014), it does not examine the effect of damaged banks on the probability of bankruptcy or the natural selection of the banks' borrowers.

From our analysis, we consistently find that our proxies for the banks’ damage have negative and statistically significant coefficients. This finding implies that the damage to the main bank decreases the bankruptcy probability of its borrowing firms, which is inconsistent with the prediction that financial shocks from damaged banks have a positive impact on the probability of a

${ }^{2}$ We thus rely on geographical information as a proxy for the firms' damage, because no firm-level information on their damage is available. 
firm's bankruptcy. Further, we also find that as our measure of firm efficiency increases, the probability of bankruptcy decreases both for the firms transacting with damaged main banks and for those transacting with undamaged ones. This finding supports the natural selection. However, we find that the natural selection is weakened, in a relative sense, when the main bank is damaged; that is, the sensitivity of the probability of bankruptcy with respect to firm efficiency is smaller for firms transacting with damaged main banks than for those transacting with undamaged ones.

Because the finding of the decreased probability of bankruptcy for (less efficient) firms is somewhat counterintuitive, we further examine a potential underlying mechanism through which damaged banks reduce the bankruptcies of their borrowers. One of the possible factors that could explain our finding is the presence of many policy measures that targeted the banks in the affected area. Most importantly, the damaged banks that obtained a public capital injection from the government of Japan might have been able to increase their lending capacity, lend to (even less efficient) borrowers, and promote survival of the borrowers. To examine this hypothesis, we compare the bankruptcies of borrowers of damaged banks depending on whether the banks obtained an injection of public capital. Both the univariate and multivariate analyses show some evidence that the probability of bankruptcy is indeed smaller for the borrowers of damaged banks that obtained the public capital injection, especially when the borrowers were less efficient.

This paper contributes to two different strands of the literature. First, as indicated at the outset, this paper is related to the literature on the effect of financial shocks on the real activities of firms. Among the many studies, the closest to ours examine the impact of financial shocks inflicted by an exogenous change in the economic conditions for bankruptcy or loan default (Khwaja and Mian 2008; Schnabl 2012). Our paper differs from these papers in that we take advantage of a shock 
created by a natural disaster and in that we also focus on natural selection.

Second, this paper is also related to the studies on the impact of natural disasters on economic activities. There are many studies on this impact on economic growth, and some studies even report a positive impact on the productivity of the economy's corporate sector (e.g., Skidmore and Toya 2002, Crespo Cuaresma et al. 2008). There are also a few studies that focus on the impact of a natural disaster on a firm’s recovery afterwards (Leiter et al. 2009, De Mel et al. 2011), its supply chain networks and its recovery (Todo et al. 2014, Carvalho et al. 2014), its relocation (Ono et al. 2014, Siodla 2013), and on its bankruptcy (Cole et al. 2013, Uchida et al. 2014). The present paper is different from these studies because we do not focus on damaged firms but on undamaged firms (i.e., those located outside the affected area) to extract a purely exogenous financial shock from the damaged banks. ${ }^{3}$

The remaining part of this paper is comprised of the following. The next section explains the data and empirical method. Section 3 reports the results. In Section 4, we extend the analysis by taking into account the effect of a public capital injection on the banks. The final section concludes the paper.

\section{Data and empirical method}

\subsection{Data and sample selection}

We obtain the firm-level data that comprises the information on bankruptcies, characteristics,

${ }^{3}$ Similar to the present paper, using data after the Hanshi-Awaji Earthquake in Japan, Hosono et al. (2012) and Miyakawa et al. (2014) examine the capital investments and exports of undamaged firms transacting with damaged or undamaged banks (as well as those of damaged firms). They find evidence for a negative effect of financial shocks. Also, Berg and Schrader (2012) examine the effect of a volcanic eruption in Ecuador and find a smaller approval rate for microfinance after the eruption. 
and their banks from the Teikoku Databank Ltd. (TDB), which is one of the top business credit information bureaus in Japan. From this data set, we select the firms whose headquarters were located in the six prefectures of the Tohoku area of Japan (Aomori, Iwate, Miyagi, Akita, Yamagata, and Fukushima) when the Great Tohoku Earthquake hit the region. We do not use firms outside these six prefectures because most of our sample firms are SMEs and are not likely to borrow at a distance from the damaged banks in these prefectures. Further, using firms outside of this area could increase the region-specific differences among the sample firms.

Within the six prefectures, we have information on the bankruptcy status of 98,070 firms during the post-earthquake period of March 2011 to November 2012. Of the six prefectures, some area were seriously damaged by the earthquake, but many other parts were not severely damaged. This is because the direct damage from the earthquake was not severe. The serious damage was mostly due to the tsunamis in the coastal area that faces the Pacific Ocean and the accidents at the Fukushima Dai-ichi nuclear plants. We define the affected area as those cities and towns that were designated as seriously damaged in the Japanese government’s Act Concerning Special Financial Support to Deal with a Designated Disaster of Extreme Severity, and eliminate the firms within this area from our data set. ${ }^{4}$ This reduces the number of firms to 62,193.

We further eliminate those firms for which there are any missing characteristic variables or information to identify their main banks. We also eliminate the firms that belong to financial industries and those for which no industry information is available. As for the identification of the firms' main banks, we use a list of the banks with which the firms transact. In this list, the banks are

\footnotetext{
${ }^{4}$ In this selection, we use the addresses of the firms' headquarters. We have no information on the firms' establishments, but the majority of our sample firms are SMEs that typically have only one establishment (i.e., the headquarters).
} 
listed in the order of importance to the firms based on their subjective evaluation. Following a widely used convention, we define the bank listed at the top as the firm's main bank. As a result, we have 53,904 firms in our sample.

We augment this data set with the data on these main banks. We add variables from the banks' financial statements that are obtained from the Nikkei NEEDS Financial Quest compiled by Nikkei Inc. (Nihon Keizai Shimbunsha) and the financial statements of Shinkin Banks and Credit Cooperatives from the Kin-yu Tosho Consultant Corporation. We further augment the data set with information on the location (address) of the main banks' branches, which is obtained from Nihon Kin-yu Meikan of Nikkin Publishing. Because the financial statements are not available for certain types of banks, those firms whose main bank is not a city bank, regional bank, Shinkin bank, or a credit cooperative are not included in our sample of 53,904 firms. ${ }^{5}$

\subsection{Regression and variables}

\subsubsection{Regression and main variables}

We examine the effect of the damage on the firms' main bank by running a probit regression that takes the following form:

$$
\operatorname{Pr}\left[\text { BANKRUPTCY }_{\mathrm{i}}=1\right]=\operatorname{Pr}\left[y_{\mathrm{i}}^{*}>0\right],
$$

where

$$
y_{\mathrm{i}}^{*}=\mathbf{X}_{\mathrm{i}} \mathrm{b}+\mathrm{e}_{\mathrm{i}}
$$

\footnotetext{
${ }^{5}$ Lenders of the firms excluded from the sample are government-owned banks, labor banks (Roudou kinko in Japanese), agricultural cooperatives (Nougyou kyoudou kumiai in Japanese), fishery cooperatives (Gyogyou kyoudou kumiai in Japanese), and the cooperatives' central banks (Sinyou nougyou kyoudou kumiai rengoukai and Shinyou gyogyou kyoudou kumiai rengoukai in Japanese) and internet banks.
} 
and $\mathrm{i}=1, \ldots, \mathrm{N}$ is an indicator for each of the $\mathrm{N}$ sample firms.

Our main variable is a dummy variable, BANKRUPTCY, that takes the value of one when the firm is recorded as going bankrupt during the post-earthquake period from March 2011 to November 2012 and zero otherwise. We focus on bankruptcy and do not focus on other forms of exit, such as voluntary closures and M\&As. This is not only because bankruptcy is one of the most important forms of exit, but also because we are interested in the effect of financial shocks. Different from other forms of exit, bankruptcy is by definition invariably associated with a firm's default on its debt. We assume that the probability of bankruptcy, $\operatorname{Pr}[\mathrm{BANKRUPTCY} i=1]$, is determined by the value of a latent variable $y_{\mathrm{i}}{ }^{*}$ that is determined by a vector $\mathrm{X}_{\mathrm{i}}$ of independent variables and the ordinary error term $\mathrm{e}_{\mathrm{i}}$. To circumvent any endogeneity, we use the pre-earthquake values of the independent variables, except for the proxies for earthquake damage. ${ }^{6}$

The main independent variable included in the vector $\mathrm{X}_{\mathrm{i}}$ is a proxy for bank damage, which we label B_DAMAGED. We use two alternative variables as proxies for bank damage. As explained above, the sample firms' main banks are those listed at the top of the banks they transact with. Our first proxy, B_HQDAMAGED, is a dummy variable that takes the value of one if the main banks' headquarters are located inside the affected area (designated by the Japanese Government's Act Concerning Special Financial Support to Deal with a Designated Disaster of Extreme Severity as severely damaged) and zero otherwise. Our second proxy B_BRDAMAGED is created based on information on the location of the main banks' branch offices. The variable B_BRDAMAGED is the ratio of the number of the main banks' branches inside the affected area to the total number of

${ }^{6}$ More precisely, the variables are as of year 2010 (January to December 2010). As for the variables from the banks' financial statements, we use the values at the end of the fiscal year 2010 (i.e., March 31, 2011), because the values are not likely to be affected by the earthquake that happened on March 11. For some firms, TDB collects information at multiple data points within 2010, but we only use the most recent data. 
the branch offices of the main banks. By their nature, these two alternative proxies capture the different aspects of the damage that the main bank suffered. The B_HQDAMAGED is likely to capture the decline in the banks' managerial capacity to process loan applications at their headquarters, while B_BRDAMAGED is likely to capture the decline in the banks' financial health and risk-taking capacity.

The descriptive statistics for these main variables are shown in the first three rows of Table 1. In this table, column (1) reports the statistics for the whole sample (for regressions), but the table also shows the statistics when we divide the sample depending on the value of B_HQDAMAGED (columns (2) and (3)). In column (4), we report the results for the test of equal means of the relevant variable between the two subsamples.

As explained above, we have 53,904 firms in our sample which are located in the six prefectures in Tohoku but outside the affected area. From the first row of this table, we find that the overall bankruptcy rate for these firms (column (1)) is $0.516 \%$. If we focus on those firms whose main banks are headquartered outside the affected area (B_HQDAMAGED=0) (column (2)), the rate is slightly higher at $0.555 \%$, but when the main banks are headquartered inside the area (B_HQDAMAGED=1) (column (3)), the rate is smaller at $0.349 \% .^{7}$ From column (4), we find that the difference between the two is statistically significant. ${ }^{8}$ This significance seems to suggest that the damage to main banks weakens the bankruptcies of their borrowers. However, we cannot draw a conclusion without controlling for many of the other factors that affect the firms' bankruptcies.

\footnotetext{
${ }^{7}$ Similar to these results, when we alternatively divide the sample into the cases where not only the main banks' headquarters but also at least one of their branches are located inside the affected area and the other case, the bankruptcy rates are $0.349 \%$ in the former case, and $0.594 \%$ in the latter.

8 These results are qualitatively unchanged even if we do not eliminate those firms for which variables other than Bankruptcy and B_HQDAMAGED are not available and thereby expand the number of observations.
} 
The second and the third rows of this table show the summary statistics for our two proxies for bank damages. We find that the firms whose main banks are located inside the affected area (i.e., B_HQDAMAGED = 1) account for $19 \%$ of the whole sample. If we measure the bank's damage by the fraction of branch offices inside the affected area (B_BRDAMAGED), we find that the average main bank in our sample has $21 \%$ of its branch offices inside the affected area. Columns (2) and (3) show the breakdown of this fraction depending on the value of B_HQDAMAGED. Naturally, the fraction is higher when B_HQDAMAGED = 1, but we also find from column (2) that even for the firms transacting with main banks headquartered outside the affected area, $11 \%$ of the banks' branches are inside the affected area.

\subsubsection{Proxy for firm efficiency}

We are not only interested in the impact of the damaged bank on the probability of bankruptcy but also in its impact on the sensitivity of the probability of bankruptcy to the firms' efficiency, that is, the natural (or unnatural) selection of the borrowing firms. To examine whether the mechanism is natural or unnatural, we need a proxy for efficiency. The most widely used proxy is the total factor productivity (TFP) defined in various ways. But to create even a crude measure of TFP, we need the firms' financial statements. Because most of our sample firms are SMEs, comprehensive information on financial statements is available for only a small subset of them.

As an alternative but informative measure of the firms' efficiency, we use the their score, F_SCORE, reported by TDB. The TDB's score evaluates a firm based on its business history, capital structure, size, profitability, funding status, CEO, and vitality. ${ }^{9}$ As evident from such a wide

\footnotetext{
${ }^{9}$ Specifically, the score is composed of the sub-scores on a firm's business history (including age) (5\% of the
} 
scope of evaluation, the score does not represent a credit score that is ordinarily used to measure insolvency risk (creditworthiness) only but instead measures the overall managerial efficiency of the firms. ${ }^{10}$ The score takes an integer value on a 1-100 scale. Although the evaluation is partly based on the TDB researchers' subjective evaluation, the score is calculated on an unsolicited basis (i.e., the firms do not pay for being rated), so it is widely used in practice, for example, when a firm wants to evaluate a potential trade partner. ${ }^{11}$

Uchida et al. (2014) find evidence that supports the natural selection of the firms after the Great Tohoku Earthquake. Using a data set based on the TDB database, they find that the probability of bankruptcy after the Great Tohoku Earthquake is lower for firms with a higher score, and that the result does not differ between the areas inside and outside the affected area. In this paper, we examine whether and how the damaged bank affects the negative association between the firms' score and the probability of bankruptcy by focusing on firms located outside the affected area. In this vein, we use an interaction term of a firm's score and a proxy for the bank's damage (B_HQDAMAGED or B_BRDAMAGED). We also add the F_SCORE in isolation in the vector of the independent variable $\mathbf{X}_{\mathrm{i}}$. As shown in the fourth row of Table 1, an average score for our sample firms is 45.6. We also find that the score is slightly higher for firms with B_HQDAMAGED $=0$

score), capital structure (financial stability) (12\%), size (e.g., sales and the number of employees) (19\%), profitability (surplus/deficits on the financial statements) (10\%), funding status (business condition, credit correction/payment, fund-raising ability) (20\%), CEO (e.g., managerial experiences, personal wealth) (15\%), vitality (personnel, trade counterparts, salability, future prospects) (19\%), and the TDB researchers' subjective evaluation on other aspects (as additional/subtracted points). See the TDB's webpage for more information. In a later section, we use a subset of these sub-scores in our estimation to check the robustness of our empirical results.

10 The TDB itself reports this score as the firms' overall evaluation. In fact, they provide a separate indicator called the "predicted value for bankruptcy" (tousan yosokuchi in Japanese) that does explicitly measure the firms' creditworthiness.

${ }^{11}$ As proxies for firm efficiency, Peek and Rosengren (2005), for example, use variables such as the firms' ROA or working capital ratio. Compared with these measures, the scores that we use are relatively subjective but potentially include more information than that contained in these publicly observable variables. 
than those with B_HQDAMAGED = 1 .

\subsubsection{Control variables}

To single out the effects of a damaged bank and a firm's efficiency on the probability of bankruptcy, we use a number of control variables. The definition and the descriptive statistics of these variables are in the second column of Table 1 . We first use three controls for the firm's characteristics: F_EMP is the number of employees (firm size), F_AGE is the age of the firm, and F_NBANK is the number of banks that the firm transacts with. We also include industry dummies in our regression. ${ }^{12}$ From Table 1 , we find that our sample firms on average hire 13 employees, are 30 years old, and transact with 2 banks.

We also use variables to represent the lender bank's characteristics. Three variables are from the main banks' financial statements: B_ROA is the return on assets (defined as ordinary profit over total assets), B_CAP is the book-based capital asset ratio, and B_lnASSET is the total assets (in natural logarithm). To differentiate the effect of different bank types, we also use three bank-type dummies: B_REGIONAL, B_REGIONAL2, and B_SHINKIN to respectively indicate that the main bank is a regional bank, a second-tier regional bank, or a Shinkin bank. ${ }^{13}$ Typically, regional banks are medium-sized banks whose banking operations are regionally concentrated. Second-tier regional banks also operate regionally but they tend to be smaller in size, and Shinkin banks are cooperative banks that specialize in commercial banking services to member SMEs and

12 The industries that our 53,904 sample firms belong to are: Agriculture, Forestry, or Hunting (1.04\%), Services (0.25\%), Construction (36.59\%), Manufacturing (11.64\%), Wholesale (9.76\%), Retail or Restaurants (18.86\%), Transportation, IT, or Utilities (3.20\%), and Real estate (3.21\%).

${ }^{13}$ Out of the 53,904 firms we use for our empirical analysis, more than $80 \%$ of firms have either a regional bank or a second-tier regional bank as their main banks. 
individuals. ${ }^{14}$ The coefficients of these dummies measure the difference in the firms' probability of bankruptcy in relation to each type of bank that is the main bank as compared with a city or trust bank that is the main bank. City banks are the largest in size and operate nationwide, and trust banks can offer trust services in addition to commercial banking services.

Table 1 shows that there are significant differences in both the variables for the firms' and the banks' characteristics across the cases where the firms' main banks are damaged or undamaged. These findings strongly suggest a need to control for these variables when examining the effects of the damaged bank on the firms’ probability of bankruptcy.

\section{Results}

\subsection{Baseline results}

Table 2 shows our baseline regression results. Columns (1) and (2) of this table report the results when we use B_DAMAGED only, and columns (3) and (4) report the results when we add the interaction term of B_DAMAGED and F_SCORE to the list of explanatory variables. The damaged bank variable B_DAMAGED is either B_HQDAMAGED (headquarter's damage) in columns (1) and (3), or B_BRDAMAGED (branch’s damage) in columns (2) and (4). The figures in the columns named $\mathrm{dF} / \mathrm{dx}$ are the marginal effects of the respective variables, those in the "p-value" columns are the p-values of the estimates; and ${ }^{* * *}, * *$, or $*$ respectively indicates that the null hypothesis of the coefficient of zero is rejected at the $1 \%, 5 \%$, or $10 \%$ significance level. The p-values are calculated by using the heteroskedasticity robust standard errors.

From the estimation results, we first find that most of the control variables are statistically

\footnotetext{
${ }^{14}$ See Uchida and Udell (2010) for more information on the types of banks in Japan.
} 
significant. Specifically, the estimates of the marginal effects indicate that the probability of bankruptcy is higher for larger (F_EMP) and older (F_AGE) firms, and for those transacting with a larger number of banks (F_NBANK). Compared with the borrowers of city or trust banks, the probability is higher for borrowers of regional banks (B_REGIONAL), and higher still for borrowers of second-tier regional (B_REGIONAL2) and Shinkin banks (B_SHINKIN). We also find that the borrowers of less profitable (B_ROA) and less capitalized (B_CAP) banks have a higher probability of bankruptcy. The finding for B_CAP is consistent with the capital crunch theory, where less-capitalized banks shrink their loans to keep the minimum regulatory capital ratio and therefore triggering the defaults of the borrowing firms (e.g., Peek and Rosengren 1995).

Second, the main independent variable in this study is B_DAMAGED that is a proxy for a damaged bank. We consistently find that the coefficients for our damaged bank proxies are negative and statistically significant. Regardless of whether we measure damage by the headquarters of the main bank being located inside the earthquake-affected area (B_HQDAMAGED) or a larger fraction of branch offices of the main bank being located inside the area (B_BRDAMAGED), the probability of a firm's bankruptcy is lower when it transacts with a damaged bank. The coefficient in column (1) indicates that the probability of bankruptcy for firms whose main banks are damaged is 0.174 percentage points lower than that for firms transacting with undamaged main banks. Alternatively, the coefficient in column (2) indicates that a one point increase in B_BRDAMAGED decreases the probability of bankruptcy by 0.414 percentage points, which leads to a 0.190 percentage point increase for a two-standard deviation $(0.23 \times 2$ : see column (1) of Table 1$)$ increase in B_BRDAMAGED. Because the average bankruptcy rate is $0.516 \%$ (column (1) in Table 1), these effects are economically significant. 
Third, turning to the results regarding natural selection, we consistently find that the firms' score (F_SCORE) has a negative and statistically significant coefficient. ${ }^{15}$ This means that higher-scored firms are less likely to go bankrupt. This finding is consistent with the natural selection, and is consistent with the main finding in Uchida et al. (2014). However, from columns (3) and (4), we find that the interaction term of B_DAMAGED and the firms' score (F_SCORE) has a positive and statistically significant coefficient. This coefficient means that irrespective of whether it is measured by a damaged headquarters or a damaged branch, a damaged bank weakens the natural selection. ${ }^{16}$ If the positive effect of the interaction term surpasses the negative effect of F_SCORE, then it means that the selection of firms is unnatural when B_DAMAGED $=1$. Our finding in column (3) shows that although the bank damage weakens the natural selection of firms, it does not turn the selection unnatural because the absolute value of the estimated coefficient for the interaction term is smaller than that of the F_SCORE.

Our findings of the negative impacts of B_DAMAGED on the probability of bankruptcy and its sensitivity to a firm's efficiency are inconsistent with the prediction that damaged banks are likely to have a smaller lending capacity due to the malfunctioning of their back-office operations, destroyed physical and/or human capital at the branches, and deteriorated capital caused by damaged and consequently poorly performing borrowers. Among the possible underlying mechanisms through which the negative impacts of B_DAMAGED on the borrower's bankruptcy and natural selection arise, we focus on the capital injection provided to the damaged banks by the

15 The results are qualitatively similar even if we take the natural logarithm of F_SCORE to account for the nonlinear impact of firm efficiency.

${ }^{16}$ Note that we use the term "weakens" in a relative sense, i.e., to compare firms transacting with damaged and undamaged banks in terms of the sensitivity of firms' probability of bankruptcy to their efficiency after the earthquake. We cannot make an absolute judgment on the optimality of the selection, because we have no yardstick against which we can evaluate whether the natural selection is excessive or insufficient. 
government in Section 4.

\subsection{Illustrative representation of the results}

In this subsection, we provide an illustrative representation of our findings in Table 2 to draw a complete picture of the effects of damaged banks on the firms' probability of bankruptcy. Figure 1 depicts the relation between the probability of bankruptcy and the firms' scores. The gray line with markers is for the firms that borrow from damaged main banks (B_HQDAMAGED $=1$ ), and the black line is for those that borrow from undamaged ones (B_HQDAMAGED $=0$ ). The height of each line (Y-axis) indicates the predicted probabilities measured at different values of the F_SCORE (X-axis) between the region around its mean (45.61: see Table 1) plus or minus two sigmas (i.e., two standard deviations: $5.62 \times 2$ ). To calculate the predicted probabilities, we first calculate the predicted values of the latent variable $y_{\mathrm{i}}{ }^{*}$ for the specification in column (3) of Table 2 and then obtain the corresponding probabilities that follow the standard normal distribution. ${ }^{17}$

From the figure, we first find that the two lines are downward sloping. This slope confirms our interpretation of the natural selection of firms (irrespective of the presence or absence of damaged banks). We also find that the gray line is located below the black one and that the slope of the gray line is flatter. These differences stem not only from the negative coefficient for B_HQDAMAGED but also from the positive coefficient for B_HQDAMAGED $\times$ F_SCORE. ${ }^{18}$ These findings confirm

\footnotetext{
17 Specifically, we first sum the products of the means of the independent variables and their estimated coefficients (for the independent variables other than the first three). We then add the product of the value of the F_SCORE (shown on the X-axis) and its estimated coefficient. For the gray line, we further add the estimated coefficient for B_HQDAMAGED.

${ }^{18}$ Note that even if the coefficient for the cross term is zero, the slope of the gray line will be flatter as long as the coefficient for B_HQDAMAGED is negative. Due to the nonlinearity of the probit model, the impact of B_HQDAMAGED (times its coefficient) is not uniform and depends on the value of the F_SCORE.
} 
our interpretation that damaged banks weaken the natural selection. In this figure, we can also find that the difference in the probability of bankruptcy for firms transacting with damaged and undamaged banks tends to disappear as the firms' score increases. This is because as the value of the F_SCORE increases, its effect becomes economically dominant and the marginal impact of B_HQDAMAGED (either in its isolation or through its interaction with F_SCORE) becomes smaller.

\subsection{Robustness Checks}

\subsubsection{Subperiod analysis}

In this subsection, we conduct various robustness checks of the results presented above. We first examine whether our results change between different subperiods. Specifically, we first split the sample period into the one year from March 2011 to February 2012, and second into the nine months from March 2012 to November 2012. We then estimate the same probit model for each subperiod. ${ }^{19}$ From this analysis, we can check whether our findings are robust to different periods, or whether the mechanism of firm bankruptcy differs across periods. The numbers of bankrupt firms for the two subperiods are 205 and 195 respectively.

Panels A and B of Table 3 show the results for the first and the second subperiods respectively. While the coefficient that is associated with the F_SCORE is negative and significant in both subperiods, the significance levels of the coefficients associated with B_DAMAGED and of its interaction with the F_SCORE differ between the two subperiods. Specifically, B_DAMAGED and

19 We do not estimate a panel probit model. If we did, then the firms with some specific characteristics (e.g., low F_SCORE) would tend to go bankrupt in the first subperiod and would not appear in the second subperiod. This would cause a serious survival bias in our analysis of the firms' bankruptcies. 
its interaction with the F_SCORE have respectively negatively and positively significant coefficients in the first subperiod but most of them, except for the result in the column (2), are not statistically significant away from zero in the second subperiod. These results suggest that the effect of damaged banks on the firms' bankruptcies is short-lived and only appears in the period immediately after the earthquake.

\subsubsection{Excluding subsidiaries of listed firms}

We also check whether our findings are robust to excluding the subsidiaries of the listed firms from our data set. These subsidiaries might be able to obtain financial and physical support from their parent firms that are financially viable and are located further away from the Tohoku area. Thus, they might be less likely to go bankrupt even when they face financial difficulties. To identify the subsidiaries, we use the information on shareholders stored in the TDB database and exclude firms if their major shareholders (i.e., shareholders whose ownership is $100 \%$ ) are listed firms. The shareholder information is available for 2,589 firms only, and we exclude 262 as subsidiaries. ${ }^{20}$ Table 4 reports the results based on this refined data set. The estimate results indicate that the results do not substantially change either qualitatively or quantitatively from the baseline results. Specifically, all of the control variables have similar marginal effects on the probability of bankruptcy as in the baseline estimation in Table 2, and B_DAMAGED and its interaction with the F_SCORE have respectively negatively and positively significant coefficients as in the baseline estimation. This result confirms the robustness of our empirical results.

20 As a robustness check, we also use a different definition for subsidiaries based on $50 \%$ or more ownership (338 firms were excluded), but the results are qualitatively unchanged. 


\subsubsection{Single versus multiple transacting banks}

As explained in subsection 2.1, the main bank in our analysis is the top-listed bank on TDB's list of the firms' lender banks. However, the impact and/or the behavior of the main banks might differ depending on the strength of their relationships with the firms. Although we do not have information such as loan shares or whether the lender banks have stocks of their client firms, we can use the information on the number of banks that the firms transact with as a proxy for the strength of the main banks' relationships with the firms. For this purpose, we construct a single transacting bank dummy (F_B1) that takes the value of one if the firm transacts with a single bank and zero otherwise. We add this dummy, together with its interactions with the F_SCORE, and with the F_SCORE and B_DAMAGED on the right-hand side of the regression. From the estimate results

summarized in Table 5, contrary to our expectation, we find that none of these added variables (i.e., F_B1, F_B1×F_SCORE, and F_B1×F_SCORE×B_DAMAGED) is statistically different from zero. This result confirms that a damaged bank on top of the TDB's list significantly affects the probability of bankruptcy regardless of the total number of banks in the list.

\subsubsection{An alternative measure of the firms' efficiency}

In our empirical analyses, we use the firms' score (F_SCORE) computed by the TDB as our proxy for the firms' efficiency. This is simply because it is one of the best measures representing efficiency available to us. The score is calculated based on the evaluation of the firms from multiple aspects, such as profitability, financial stability, and managerial competence. Moreover, the computation procedure is open to the public. We therefore think the score is an appropriate measure 
for the firms' efficiency. ${ }^{21}$ Nonetheless, one shortcoming associated with this score is its inclusion of the firms' leverage as one of the components in the computation of the score that accounts for the capital structure (financial stability). Although the contribution of the leverage component to the score is not substantial, our finding of a positive impact of the F_SCORE on the probability of bankruptcy might more or less reflect the tendency that more levered firms are more likely to go bankrupt. $^{22}$

To respond to such a criticism, we construct a modified score as a better proxy for efficiency. In the TDB database, the information of the decompositions of the score is available, and so we calculate the score that excludes the capital structure element. Table 6 shows the results from using this new efficiency variable (F_SCORE_ALT), the summary statistics of which is in the fifth column of Table 1 . The results do not virtually change from the baseline results except for the interaction term of the new efficiency measure and B_HQDAMAGED, which is positive with a marginal significance level of $10.6 \%$, which confirms the robustness of our baseline results to a large extent.

\section{Public capital injection}

On balance, we find that the damaged main banks decrease the probability of bankruptcy of their borrowers and weaken the natural selection of firms (i.e., reduce the bankruptcies of less

\footnotetext{
${ }^{21}$ We cannot use efficiency proxies such as the SAF index developed by Shirata (2003), because such proxies require a substantial amount of financial statement information. Our data set does not contain enough observations of firms accompanied by such detailed financial statement information.

22 To reinforce this robustness check, we also conduct another check by additionally excluding the "funding status" sub-score that may also (potentially) reflect the creditworthiness of the firms (see footnote 9 for the composition of the TDB's score). The results are qualitatively similar to those excluding the "capital structure" sub-score only, and thus are not reported below to save space.
} 
efficient borrowers). These findings are inconsistent with the prior prediction that damaged banks have deteriorated lending capacities that increases the bankruptcies of their borrowers through severer financial constraints. In this sense, our findings appear to be counterintuitive.

Nonetheless, by taking into account the economic environment after the Great Tohoku Earthquake, we can conjecture on one possible interpretation that is consistent with our findings. After the earthquake, various policy measures were taken to rescue the financial institutions in the affected area. ${ }^{23}$ Most importantly, the banks in Tohoku obtained capital injections from public funds. This injection might have contributed to an increase in the lending capacity of the banks in the affected area, enabled them to provide more funds to (less efficient) firms, and thereby allowed these firms to survive. ${ }^{24}$

To explore this possibility, we take into account the effects of the public capital injection in our analysis. During our sample period from March 2011 to November 2012, the government of Japan injected capital into 11 financial institutions based on special earthquake-related provisions of the Act on Special Measures for Strengthening Financial Functions after the Earthquake. ${ }^{25}$ Table 7

${ }^{23}$ Numerous policy measures were also implemented to help the damaged firms. However, because we focus on the firms located outside the affected area, it is unlikely that these measures have significant effects on our findings.

${ }^{24}$ Another important measure was the rescue funding by the Bank of Japan. From May 2011, the Bank of Japan started to supply funds to the financial institutions in the disaster area through special operations that aimed at supporting such financial institutions to meet the demand for funds for restoration and rebuilding. However, we do not focus on this rescue funding because the funding was mostly a measure to help short-term financing in the aftermath of the earthquake. Also, the information (especially bank-level information) to examine its effect is not available.

25 The 11 institutions are 4 banks (Sendai (Sep. 2011), Tsukuba (Sep. 2011), The 77 (Dec. 2011), and Tohoku (Sep. 2012)), 4 Shinkin Banks (Miyako (Feb. 2012), Kesennuma (Feb. 2012), Ishinomaki (Feb. 2012), and Abukuma (Feb. 2012)), and 3 credit cooperatives (Soso (Jan. 2012), Iwaki (Jan. 2012), and Nasu (Mar. 2012)). Note that after our sample period, Kirayaka Bank (Dec. 2012) and Gumma-Mirai Shinkumi Bank (Dec. 2012) also obtained the capital injection. Among these 11 institutions, B_HQDAMAGED $=1$ for 8 of them (Sendai, The 77, Miyako, Kesennuma, Ishinomaki, Abukuma, Soso, and Iwaki). See the webpages of the Deposit Insurance Corporation for more information on these injections. 
shows the decomposition of our sample firms depending on whether their main banks obtain this injection (before bankruptcy, for bankrupt firms) together with whether the main banks are headquartered in the affected area (i.e., whether B_HQDAMAGED $=0$ or 1 ).

In the first row, we find that 5,232 firms (9.7\%) out of our 53,904 sample firms have main banks that obtain the injection. ${ }^{26}$ In the second and the third rows of Table 7, we decompose the figures depending on whether or not the firms went bankrupt (i.e., whether BANKRUPTCY $=0$ or 1). The bankruptcy rate in the absence of the injection is on average higher $(0.57 \%$ or $0.38 \%)$ than the rate with the injection $(0.27 \%$ or $0.29 \%)$. The ratio of bankrupt firms seems to decrease due to the capital injection both for undamaged banks (B_HQDAMAGED $=0$ : from $0.57 \%$ to $0.27 \%$ ) and for damaged banks (B_HQDAMAGED $=1$ : from $0.38 \%$ to $0.27 \%$ ). The larger decrease for undamaged banks implies a larger effect of the injection on undamaged banks than on damaged ones. However, this is a mere comparison using univariate results; to single out the true effects of a capital injection on the probability of bankruptcy for the banks' borrowers, we need to control for various firm and bank characteristics.

To formally examine the impact of the public capital injection on the probability of bankruptcy for firms with damaged banks, we extend the analysis in Section 3 and run the probit regression by adding the ratio of the amount of capital injected after the earthquake (available from the webpage of the Deposit Insurance Corporation) to the total amount of capital as of March 2011 (from the

\footnotetext{
${ }^{26}$ It is worthwhile to note that there are some damaged banks that did not obtain a capital injection, and some undamaged banks that did obtain an injection. Table 7 shows that among the firms with damaged main banks (B_HQDAMAGED = 1: 10,319 firms (= 3392 + 6927)), 67.1\% (6927 / 10319) of them have the main banks that did not receive a capital injection. Also, among the firms with undamaged main banks (B_HQDAMAGED = 0: 43,585 firms), $4.22 \%$ of them have the main banks that did receive a capital injection. The presence of these banks implies that the effect of our damaged bank variables (especially B_HQDAMAGED) in the previous section and the effect of the capital injection are different.
} 
banks' balance sheets), which we label B_INJECTION. ${ }^{27}$ Table 8 reports the results where we include B_INJECTION (in its isolation), its interaction with the F_SCORE and B_DAMAGED $\times$ B_INJECTION, as well as the triple interaction term $($ F_SCORE $\times$ B_DAMAGED $\times$ B_INJECTION). The damaged bank variable (B_DAMAGE) is B_HQDAMAGED in column (1), and is B_BRDAMAGED in column (2).

Our findings in Table 8 lend some support to the hypothesis that the public capital injection increases the main banks' lending capacities and contributes to the survival of their (inefficient) borrowers. In columns (1) and (2), the coefficients for B_INJECTION are negative and statistically significant. This finding means that the probability of bankruptcy is lower when the firms' main banks receive the capital injection, and is consistent with the finding in Table 7. Because B_DAMAGED $\times$ B_INJECTION is insignificant, the effect of B_INJECTION does not differ depending on whether the main banks are damaged or not. We also find that F_SCORE $\times$ B_DAMAGED turns insignificant and instead the triple interaction term in column (1) is positive and statistically significant. This finding for the triple interaction term indicates that our previous finding of damaged banks demoting the natural selection is driven by damaged main banks that obtain the capital injection.

However, our findings in Table 8 also suggest that we cannot tell the whole story based on the effect of the capital injection only. This is because in columns (1) and (2), B_DAMAGED is still negative and statistically significant. Because we have separate controls for the capital injection to main banks in these columns, our finding of the negative impact of B_DAMAGED implies that the

27 The mean and the standard deviations of B_INJECTION computed for the firms are 0.037 and 0.184 . The mean and standard deviations for the firms with B_HQDAMAGED $=1$ are 0.019 and 0.090 while those for B_HQDAMAGED=0 are 0.113 and 0.367 . 
probability of the firms' bankruptcy is lower as long as the firms' main banks are damaged.

How can we interpret this unexplained effect of damaged main banks on the firms' bankruptcies? One possibility is that the damaged banks, which incurred losses from loans to damaged borrowers and consequently became undercapitalized, extended loans to non-performing borrowers to keep their regulatory capital standard satisfied. The evidence suggests that weakly capitalized Japanese banks underwrite such evergreening loans during the banking crisis in the 1990s (e.g., Sekine et al. 2003, Peek and Rosengren 2005, Fukuda et al. 2006 , Caballero et al. 2008). On the other hand, a recent study reports results that are inconsistent with this hypothesis, especially for small businesses in Japan (Sakai et al. 2010, Hamao et al. 2014). Thus, whether this hypothesis applies to our small firms is an important empirical issue.

In our analysis, we already control for the effects of the banks' capital with the variable B_CAP, but this variable is the pre-earthquake book-based capital ratio and as such is unlikely to reflect the deterioration of the capital ratios due to the earthquake. To examine whether evergreening loans play a role in our findings, we need information on the post-earthquake capital ratios that truly captures the deteriorating effect of the earthquake. Moreover, it is desirable to study the ex-post performance of the firms with damaged main banks, because some studies (Fukuda and Nakamura 2011, Nakamura and Fukuda 2013) find that the firms that are deemed to be "zombies" in the 1990s substantially recover during the 2000s. However, no such data are available to us, so the investigation on the evergreening loans after the Great Tohoku Earthquake remains an important research issue for future studies. 


\section{Conclusion}

In this paper, we investigate the impact of financial shocks caused by the firms' damaged main banks on the probability of bankruptcy by using data on the firms located outside of the area affected by the Great Tohoku Earthquake. We find that the probability of bankruptcy is smaller and the natural selection of firms is weakened when the firms' main banks are damaged. These findings are consistent with the hypothesis that public capital injections contribute to an increase in the damaged banks' lending capacity that allows these banks to extend more loans to their borrowers (especially inefficient borrowers) and enables such firms to survive. From an additional analysis that directly considers the effect of the injection on the banks, we find some evidence supporting this hypothesis.

However, even after controlling for the effect of the public capital injection, we still find that the effect of damaged banks decreases the probability of bankruptcy. One possible mechanism working behind this finding is the evergreening loans by the damaged banks. Testing this hypothesis with the appropriate data set is an important empirical issue left for future studies. 


\section{References}

Amiti, M. and D. Weinstein, (2011) Exports and Financial Shocks. Quarterly Journal of Economics 126(4): 1841-1877

Amiti, M. and D. Weinstein, (2013) How Much Do Bank Shocks Affect Investment? Evidence from Matched Bank-Firm Loan Data. NBER Working Paper 18890.

Berg, G., and J. Schrader, (2012) Access to Credit, Natural Disasters, and Relationship Lending, Journal of Financial Intermediation 21(4): 549-568.

Bertin, A.L., T.F. Bresnahan, and D.M.G. Raff, (1996) Localized Competition and the Aggregation of Plant-Level Increasing Returns: Blast Furnaces, 1929-1935. Journal of Political Economy 104(2): 241-266.

Bresnahan, T.F. and D.M.G. Raff, (1991) Intra-Industry Heterogeneity and the Great Depression: The American Motor Vehicles Industry, 1929-1935. Journal of Economic History 51(2): 317-331.

Caballero, R.J. and M.L. Hammour, (1994) The Cleansing Effect of Recessions. American Economic Review 84(5): 1350-1368.

Caballero, R.J. and M.L. Hammour, (1996) On the Timing and Efficiency of Creative Destruction. Quarterly Journal of Economics 111(3): 805-852.

Caballero, R.J. and M.L. Hammour, (2005) The Cost of Recessions Revisited: A Reverse-Liquidationist View. Review of Economic Studies 72(2): 313-341.

Caballero, R.J., T. Hoshi, and A.K. Kashyap, (2008) Zombie Lending and Depressed Restructuring in Japan. American Economic Review 98(5): 1943-1977.

Carvalho, V.M., M. Nirei, and Y.U. Saito, (2014) Supply Chain Disruptions: Evidence from the Great East Japan Earthquake. RIETI Discussion Paper 14-E-035.

Cole, M.A., R.J.R Elliot, T. Okubo, and E. Strobl, (2013) Natural Disasters and Plant Survival: The Impact of the Kobe Earthquake. RIETI Discussion Paper 13-E-063.

Crespo Cuaresma, J., J. Hlouskova, and M. Obersteiner, (2008) Natural Disasters as Creative Destruction? Evidence from Developing Countries, Economic Inquiry 46(2): 214-226.

De Mel, S., D. McKenzie and C. Woodruff, (2011) Enterprise Recovery Following Natural Disasters. Economic Journal 122: 1-28.

Fukuda, S., and J. Nakamura, (2011) Why did 'Zombie’ Firms Recover in Japan? World Economy 34: 1124-1137.

Fukuda, S., M. Kasuya, and J. Nakamura, (2006) Deteriorating Bank Health and Lending in Japan: Evidence from Unlisted Companies under Financial Distress. Journal of the Asia Pacific 
Economy 11: 482-501.

Hamao, Y., K. Kutsuna, and J. Peek, (2014) Nice to be on the A-List, mimeo, University of Southern California, Kobe University, and Federal Reserve Bank of Boston.

Hosono, K., D. Miyakawa, T. Uchino, M. Hazama, A. Ono, H. Uchida, and I. Uesugi, (2015) Natural Disasters, Damage to Banks, and Firm Investment. Forthcoming in International Economic Review.

Khwaja, A.I. and A. Mian, (2008) Tracing the Impact of Bank Liquidity Shocks: Evidence from an Emerging Market. American Economic Review 98 (4): 1413-1442.

Leiter, A.M., H. Oberhofer, and P.A. Raschky, (2009) Creative Disasters? Flooding Effects on Capital, Labor and Productivity within European Firms. Environmental and Resource Economics 43: 333-350.

Miyakawa, D., K. Hosono, T. Uchino, A. Ono, H. Uchida, and I. Uesugi, (2014) Financial Shocks and Firm Exports: A Natural Experiment Approach with a Massive Earthquake. RIETI Discussion Paper 14-E-010.

Nakamura, J. and S. Fukuda, (2013) What Happened to 'Zombie Firms' in Japan? Reexamination for the Lost Two Decades. Global Journal of Economics 2: 1-18

Ono, A., D. Miyakawa, K. Hosono, T. Uchino, H. Uchida, and I. Uesugi (2014) Transaction Partners and Firm Relocation Choice: Evidence from the Tohoku Earthquake. RIETI Discussion Paper 14-E-054.

Paravisini, D., V. Rappoport, P. Schnabl and D. Wolfenzon, (2011) Dissecting the Effect of Credit Supply on Trade: Evidence from Matched Credit-Export Data. NBER Working Paper 16975.

Peek, J. and E.S. Rosengren, (1995) The Capital Crunch: Neither a Borrower nor a Lender be. Journal of Money, Credit and Banking 27(3): 625-638.

Peek, J. and E.S. Rosengren, (2000) Collateral Damage: Effects of the Japanese Bank Crisis on Real Activity in the United States. American Economic Review 90 (1): 30-45.

Peek, J., and E.S. Rosengren, (2005) Unnatural Selection: Perverse Incentives and the Misallocation of Credit in Japan. American Economic Review 95(4): 1144-66.

Sakai, K., I. Uesugi, and T. Watanabe, (2010) Firm Age and the Evolution of Borrowing Costs: Evidence from Japanese Small Firms," Journal of Banking and Finance 34(8): 1970-1981.

Schnabl, P., (2012) The International Transmission of Bank Liquidity Shocks: Evidence from an Emerging Market. Journal of Finance 67 (3): 897-932.

Sekine, T., K. Kobayashi, and Y. Saita, (2003) Forbearance Lending: The Case of Japanese Firms. Monetary and Economic Studies 21: 69-92. 
Shirata, Y, (2003) Model for Predicting Corporate Bankruptcy. Chuo Keizaisha.(in Japanese)

Siodla, J. (2013). Making the Move: The Impact of the 1906 San Francisco Disaster on Firm Relocations. Mimeo.

Skidmore, M, and H. Toya, (2002) Do Natural Disasters Promote Long-Run Growth? Economic Inquiry 40(4): 664-687.

Todo, Y., K. Nakajima, and P. Matous, (2014) How Do Supply Chain Networks Affect the Resilience of Firms to Natural Disasters? Evidence from the Great East Japan Earthquake. Journal of Regional Science, forthcoming.

Uchida, H.,and G. Udell, (2010) Banking in Japan. In A. Berger, P. Molyneux, and J. Wilson eds. Oxford Handbook of Banking, Ch. 35, Oxford University Press.

Uchida, H., D. Miyakawa, K. Hosono, A. Ono, T. Uchino, and I. Uesugi, (2014) Natural Disaster and Natural Selection. RIETI Discussion Paper Series 14-E-055. 


\section{Tables and Figure}

Table 1 Variable Definitions and Summary Statistics

This table reports the definitions and the summary statistics of the variables for our analyses.

\begin{tabular}{|c|c|c|c|c|c|c|c|c|c|c|c|c|}
\hline \multirow[b]{2}{*}{ Variable } & & \multicolumn{3}{|c|}{ (1) Whole sample } & \multicolumn{3}{|c|}{ (2) B_HQDAMAGED $=0$} & \multicolumn{3}{|c|}{ (3) B_HQDAMAGED $=1$} & \multicolumn{2}{|c|}{$\begin{array}{l}\text { (4) t-test for } \\
\mathrm{H}_{0} \text { : mean }\left(\mathrm{B} \_ \text {HQDAMAGED }=0\right) \\
=\text { mean }\left(\mathrm{B} \_ \text {HQDAMAGED }=1\right)\end{array}$} \\
\hline & & Obs. & Mean & Std. dev. & Obs. & Mean & Std. dev. & Obs. & Mean & Std. dev. & difference & $\mathrm{p}$-value \\
\hline BANKRUPTCY & $\begin{array}{l}\text { Dummy taking a value of one if the firm is } \\
\text { recorded as a bankrupted firm after the } \\
\text { earthquake. }\end{array}$ & 53,904 & 0.00516 & (NA) & 43,585 & 0.00555 & (NA) & 10,319 & 0.00349 & (NA) & 0.00206 & $0.009 * * *$ \\
\hline B_HQDAMAGED & $\begin{array}{l}\text { Dummy taking a value of one if the } \\
\text { headquarters of the firm's main bank is } \\
\text { located in the earthquake-affected area. }\end{array}$ & 53,904 & 0.19 & (NA) & 43,585 & 0.00 & (NA) & 10,319 & 1.00 & (NA) & & (NA) \\
\hline B_BRDAMAGED & $\begin{array}{l}\text { The ratio of the number of branches of a } \\
\text { firm's main bank located in the } \\
\text { earthquake-affected area to the total } \\
\text { number of branches of that bank. }\end{array}$ & 53,904 & 0.21 & 0.23 & 43,585 & 0.11 & 0.09 & 10,319 & 0.62 & 0.16 & -0.51145 & $0.000 * * *$ \\
\hline F_SCORE & TDB's score of the firm. & 53,904 & 45.61 & 5.62 & 43,585 & 45.79 & 5.62 & 10,319 & 44.84 & 5.55 & 0.94762 & $0.000 * * *$ \\
\hline F_EMP & The number of employees of the firm. & 53,904 & 12.70 & 56.46 & 43,585 & 13.25 & 59.50 & 10,319 & 10.39 & 41.13 & 2.85583 & $0.000 * * *$ \\
\hline F_AGE & The age of the firm. & 53,904 & 30.41 & 17.85 & 43,585 & 30.37 & 17.87 & 10,319 & 30.58 & 17.77 & -0.21181 & 0.278 \\
\hline F_NBANK & $\begin{array}{l}\text { The number of banks that the firm } \\
\text { transacts with. }\end{array}$ & 53,904 & 2.05 & 1.17 & 43,585 & 2.07 & 1.18 & 10,319 & 1.97 & 1.15 & 0.09933 & $0.000 * * *$ \\
\hline B_ROA & $\begin{array}{l}\text { The ratio of operating profit to total assets } \\
\text { of a firm's main bank. }\end{array}$ & 53,904 & 0.00193 & 0.00131 & 43,585 & 0.00185 & 0.00132 & 10,319 & 0.00224 & 0.00123 & -0.00039 & $0.000 * * *$ \\
\hline$\overline{\text { B_CAP }}$ & $\begin{array}{l}\text { The equity to assets ratio of a firm's main } \\
\text { bank }\end{array}$ & 53,904 & 0.04551 & 0.01098 & 43,585 & 0.04565 & 0.01117 & 10,319 & 0.04494 & 0.01012 & 0.00071 & $0.000 * * *$ \\
\hline B_LNASSETS & $\begin{array}{l}\text { The natural logarithm of the total assets } \\
\text { owned by a firm's main bank }\end{array}$ & 53,904 & 20.95950 & 1.12796 & 43,585 & 20.89236 & 1.12679 & 10,319 & 21.24312 & 1.08816 & -0.35077 & $0.000^{* * *}$ \\
\hline B_REGIONAL & $\begin{array}{l}\text { Dummy taking a value of one if the firm's } \\
\text { main bank is a regional bank. }\end{array}$ & 53,904 & 0.66644 & (NA) & 43,585 & 0.69347 & (NA) & 10,319 & 0.55228 & (NA) & 0.14119 & $0.000 * * *$ \\
\hline B_REGIONAL2 & $\begin{array}{l}\text { Dummy taking a value of one if the firm's } \\
\text { main bank is a second-tier regional bank. }\end{array}$ & 53,904 & 0.14184 & (NA) & 43,585 & 0.12846 & (NA) & 10,319 & 0.19837 & (NA) & -0.06991 & $0.000 * * *$ \\
\hline B_SHINKIN & $\begin{array}{l}\text { Dummy taking a value of one if the firm's } \\
\text { main bank is a Shinkin bank. }\end{array}$ & 53,904 & 0.18023 & (NA) & 43,585 & 0.16386 & (NA) & 10,319 & 0.24935 & (NA) & -0.08548 & $0.000 * * *$ \\
\hline
\end{tabular}


Table 2 Probit Estimation for Bankruptcy Probability

This table reports the results for our baseline analysis on the probability of bankruptcy. The dependent variable is a dummy variable taking a value of one if the firm is recorded as a bankrupted firm during the 20 months period after the earthquake (BANKRUPTCY). The main independent variable, B_DAMAGED, is either a dummy variable taking a value of one if the headquarters of the firm's main bank is located in the earthquake-affected areas (HQDAMAGED), or the ratio of the number of branches of a firm's main bank located in the earthquake-affected areas to the total number of branches of that bank (B_BRDAMAGED). The other independent variables are TDB's score of the firm (F_SCORE), the number of employees of the firm (F_EMP), the age of the firm (F_AGE), the number of banks that the firm transacts with (F_NBANK), the ratio of operating profit to total assets of the firm's main bank (B_ROA), the capital asset ratio of the firm's main bank (B_CAP), the natural logarithm of the total assets owned by the firm's main bank (B_LNASSETS), dummy variables taking the value of one if the firm's main bank is a regional bank (B_REGIONAL), a second-tier regional bank (B_REGIONAL2), and a Shinkin bank (B_SHINKIN). ***, **, and * respectively indicate statistical significance at the 1, 5 , and $10 \%$ level.

Dependent variable: BANKRUPTCY (dummy for bankruptcy during the 21 months period after the earthquake)

\begin{tabular}{|c|c|c|c|c|c|c|c|c|}
\hline & \multicolumn{2}{|c|}{$\begin{array}{c}(1) \\
\text { B_DAMAGED } \\
= \\
\text { B_HQDAMAGED }\end{array}$} & \multicolumn{2}{|c|}{$\begin{array}{c}(2) \\
\text { B_DAMAGED } \\
= \\
\text { B_BRDAMAGED }\end{array}$} & \multicolumn{2}{|c|}{$\begin{array}{c}(3) \\
\text { B_DAMAGED } \\
= \\
\text { B_HQDAMAGED }\end{array}$} & \multicolumn{2}{|c|}{$\begin{array}{c}(4) \\
\text { B_DAMAGED } \\
= \\
\text { B_BRDAMAGED }\end{array}$} \\
\hline & $\mathrm{dF} / \mathrm{dx}$ & p-value & $\mathrm{dF} / \mathrm{dx}$ & p-value & $\mathrm{dF} / \mathrm{dx}$ & p-value & $\mathrm{dF} / \mathrm{dx}$ & p-value \\
\hline B_DAMAGED $\dagger$ & -0.00174 & $0.00 * * *$ & -0.00414 & $0.00 * * *$ & -0.00465 & $0.02 * *$ & -0.01919 & $0.00 * * *$ \\
\hline F_SCORE & -0.00039 & $0.00 * * *$ & -0.00039 & $0.00 * * *$ & -0.00042 & $0.00 * * *$ & -0.00046 & $0.00 * * *$ \\
\hline F_SCORE $\times$ B_DAMAGED $\dagger$ & & & & & 0.00014 & $0.09 *$ & 0.00035 & $0.02 * *$ \\
\hline F_EMP & 0.00001 & $0.02 * *$ & 0.00001 & $0.02 * *$ & 0.00001 & $0.02 * *$ & 0.00001 & $0.02 * *$ \\
\hline F_AGE & 0.00002 & $0.05 * *$ & 0.00002 & $0.05 * *$ & 0.00002 & $0.04 * *$ & 0.00002 & $0.05 * *$ \\
\hline F_NBANK & 0.00103 & $0.00 * * *$ & 0.00103 & $0.00 * * *$ & 0.00103 & $0.00 * * *$ & 0.00103 & $0.00 * * *$ \\
\hline B_REGIONAL & 0.29248 & $0.00 * * *$ & 0.29737 & $0.00 * * *$ & 0.28062 & $0.00 * * *$ & 0.26438 & $0.00 * * *$ \\
\hline B_REGIONAL2 & 0.99835 & $0.00 * * *$ & 0.99856 & $0.00 * * *$ & 0.99781 & $0.00 * * *$ & 0.99684 & $0.00 * * *$ \\
\hline B_SHINKIN & 0.99761 & $0.00 * * *$ & 0.99734 & $0.00 * * *$ & 0.99690 & $0.00 * * *$ & 0.99448 & $0.00 * * *$ \\
\hline B_ROA & -0.27664 & $0.03 * *$ & -0.23841 & $0.08 *$ & -0.28259 & $0.03 * *$ & -0.25130 & $0.07 *$ \\
\hline B_CAP & -0.06201 & $0.00 * * *$ & -0.05548 & $0.01 * * *$ & -0.06264 & $0.00 * * *$ & -0.05630 & $0.01 * * *$ \\
\hline B_LNASSETS & 0.00053 & 0.25 & 0.00044 & 0.29 & 0.00056 & 0.23 & 0.00047 & 0.26 \\
\hline Industry dummies & yes & & yes & & yes & & yes & \\
\hline 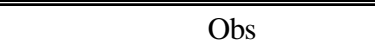 & 53904 & & 253904 & & 53904 & & 53904 & \\
\hline Pseudo R-squared & 0.0703 & & 0.0715 & & 0.071 & & 0.0728 & \\
\hline Log likelihood & -1619.1351 & & -1617.1225 & & -1617.9168 & & -1614.7860 & \\
\hline
\end{tabular}

† The B_DAMAGED variable is either B_HQDAMAGED or B_BRDAMAGED as indicated in the column heading. 


\section{Table 3 Probit Estimation for Bankruptcy Probability (Two Subperiods)}

This table reports the results for our analysis on the probability of bankruptcy when we divide the sample period for the 1 year period after the earthquake (Panel A) and the subsequent 9 month period (Panel B). The variables and the specifications are the same as those in Table $2 . * * *$, **, and * indicate statistical significance at the 1,5 , and $10 \%$ level, respectively.

(A) Bankruptcy during the 1 year after the earthquake

Dependent variable: BANKRUPTCY (dummy for bankruptcy during the 1 year period after the earthquake)

\begin{tabular}{|c|c|c|c|c|c|c|c|c|}
\hline & \multicolumn{2}{|c|}{$\begin{array}{c}(1) \\
\text { B_DAMAGED } \\
= \\
\text { B_HQDAMAGED }\end{array}$} & \multicolumn{2}{|c|}{$\begin{array}{c}(2) \\
\text { B_DAMAGED } \\
= \\
\text { B_BRDAMAGED }\end{array}$} & \multicolumn{2}{|c|}{$\begin{array}{c}(3) \\
\text { B_DAMAGED } \\
= \\
\text { B_HQDAMAGED }\end{array}$} & \multicolumn{2}{|c|}{$\begin{array}{c}(4) \\
\text { B_DAMAGED } \\
= \\
\text { B_BRDAMAGED }\end{array}$} \\
\hline & $\mathrm{dF} / \mathrm{dx}$ & p-value & $\mathrm{dF} / \mathrm{dx}$ & p-value & $\mathrm{dF} / \mathrm{dx}$ & p-value & $\mathrm{dF} / \mathrm{dx}$ & p-value \\
\hline B_DAMAGED $\dagger$ & -0.00121 & $0.01 * * *$ & -0.00238 & $0.01 * * *$ & -0.00369 & $0.01 * * *$ & -0.01510 & $0.00 * * *$ \\
\hline F_SCORE & -0.00025 & $0.00 * * *$ & -0.00025 & $0.00 * * *$ & -0.00027 & $0.00 * * *$ & -0.00031 & $0.00 * * *$ \\
\hline F_SCORE $\times$ B_DAMAGED $\dagger$ & & & & & 0.00013 & $0.03 * *$ & 0.00030 & $0.01 * * *$ \\
\hline F_EMP & 0.00000 & 0.33 & 0.00000 & 0.31 & 0.00000 & 0.34 & 0.00000 & 0.37 \\
\hline F_AGE & 0.00001 & $0.06 *$ & 0.00001 & $0.07 *$ & 0.00002 & $0.06 *$ & 0.00001 & $0.06 *$ \\
\hline F_NBANK & 0.00060 & $0.00 * * *$ & 0.00060 & $0.00 * * *$ & 0.00060 & $0.00 * * *$ & 0.00060 & $0.00 * * *$ \\
\hline B_REGIONAL & 0.12738 & $0.00 * * *$ & 0.12463 & $0.00 * * *$ & 0.11782 & $0.00 * * *$ & 0.10033 & $0.00 * * *$ \\
\hline B_REGIONAL2 & 0.95199 & $0.00 * * *$ & 0.94698 & $0.00 * * *$ & 0.93823 & $0.00 * * *$ & 0.90010 & $0.00 * * *$ \\
\hline B_SHINKIN & 0.94772 & $0.00 * * *$ & 0.92991 & $0.00 * * *$ & 0.93423 & $0.00 * * *$ & 0.87612 & $0.00 * * *$ \\
\hline B_ROA & -0.24972 & $0.01 * * *$ & -0.23945 & $0.01 * *$ & -0.25537 & $0.01 * * *$ & -0.25151 & $0.01 * * *$ \\
\hline B_CAP & -0.04586 & $0.01 * * *$ & -0.03953 & $0.01 * * *$ & -0.04655 & $0.00 * * *$ & -0.04073 & $0.01 * * *$ \\
\hline B_LNASSETS & 0.00041 & 0.23 & 0.00025 & 0.41 & 0.00044 & 0.20 & 0.00028 & 0.37 \\
\hline Industry dummies & yes & & yes & & yes & & yes & \\
\hline OPbs & 253904 & & 253904 & & 53904 & & 253904 & \\
\hline Pseudo R-squared & 0.0694 & & 0.0689 & & 0.0707 & & 0.0711 & \\
\hline Log likelihood & -1069.1103 & & -1069.6515 & & -1067.5416 & & -1067.0882 & \\
\hline
\end{tabular}

† The B_DAMAGED variable is either B_HQDAMAGED or B_BRDAMAGED as indicated in the column heading. 
Table 3 Probit Estimation for Bankruptcy Probability (Two Subperiods)

(B) Bankruptcy during the 8 months period after March 2012 (one year from the earthquake)

Dependent variable: BANKRUPTCY (dummy for bankruptcy during the 9 month period after March 2012)

\begin{tabular}{|c|c|c|c|c|c|c|c|c|}
\hline & \multicolumn{2}{|c|}{$\begin{array}{c}\text { (1) } \\
\text { B_DAMAGED } \\
= \\
\text { B_HQDAMAGED }\end{array}$} & \multicolumn{2}{|c|}{$\begin{array}{c}(2) \\
\text { B_DAMAGED } \\
= \\
\text { B_BRDAMAGED }\end{array}$} & \multicolumn{2}{|c|}{$\begin{array}{c}(3) \\
\text { B_DAMAGED } \\
= \\
\text { B_HQDAMAGED }\end{array}$} & \multicolumn{2}{|c|}{$\begin{array}{c}(4) \\
\text { B_DAMAGED } \\
= \\
\text { B_BRDAMAGED }\end{array}$} \\
\hline & $\mathrm{dF} / \mathrm{dx}$ & p-value & $\mathrm{dF} / \mathrm{dx}$ & p-value & $\mathrm{dF} / \mathrm{dx}$ & p-value & $\mathrm{dF} / \mathrm{dx}$ & p-value \\
\hline B_DAMAGED $\dagger$ & -0.00056 & 0.10 & -0.00187 & $0.02 * *$ & -0.00100 & 0.56 & -0.00449 & 0.32 \\
\hline F_SCORE & -0.00015 & $0.00 * * *$ & -0.00014 & $0.00 * * *$ & -0.00015 & $0.00 * * *$ & -0.00016 & $0.00 * * *$ \\
\hline F_SCORE $\times$ B_DAMAGED $\dagger$ & & & & & 0.00002 & 0.77 & 0.00006 & 0.56 \\
\hline F_EMP & 0.00000 & $0.01 * * *$ & 0.00000 & $0.01 * * *$ & 0.00000 & $0.01 * * *$ & 0.00000 & $0.01 * * *$ \\
\hline F_AGE & 0.00000 & 0.41 & 0.00000 & 0.41 & 0.00000 & 0.41 & 0.00000 & 0.40 \\
\hline F_NBANK & 0.00044 & $0.00 * * *$ & 0.00043 & $0.00 * * *$ & 0.00045 & $0.00 * * *$ & 0.00044 & $0.00 * * *$ \\
\hline B_REGIONAL & 0.23285 & $0.00 * * *$ & 0.25324 & $0.00 * * *$ & 0.22976 & $0.00 * * *$ & 0.24127 & $0.00 * * *$ \\
\hline B_REGIONAL2 & 0.99828 & $0.00 * * *$ & 0.99912 & $0.00 * * *$ & 0.99813 & $0.00 * * *$ & 0.99877 & $0.00 * * *$ \\
\hline B_SHINKIN & 0.99660 & $0.00 * * *$ & 0.99796 & $0.00 * * *$ & 0.99634 & $0.00 * * *$ & 0.99725 & $0.00 * * *$ \\
\hline B_ROA & 0.01554 & 0.88 & 0.05405 & 0.66 & 0.01479 & 0.89 & 0.05219 & 0.67 \\
\hline B_CAP & -0.01961 & 0.19 & -0.01999 & 0.16 & -0.01966 & 0.19 & -0.02003 & 0.16 \\
\hline B_LNASSETS & 0.00015 & 0.65 & 0.00022 & 0.46 & 0.00015 & 0.64 & 0.00022 & 0.45 \\
\hline Industry dummies & yes & & yes & & yes & & yes & \\
\hline Obs & 52172 & & 52172 & & 52172 & & 52172 & \\
\hline Pseudo R-squared & 0.0575 & & 0.0607 & & 0.0575 & & 0.0609 & \\
\hline Log likelihood & -730.7879 & & -728.3008 & & -730.7462 & & -728.1127 & \\
\hline
\end{tabular}

† The B_DAMAGED variable is either B_HQDAMAGED or B_BRDAMAGED as indicated in the column heading. 
Table 4 Probit Estimation for Bankruptcy Probability (Eliminating Subsidiaries of Listed Firms)

This table reports the results for our analysis on the probability of bankruptcy when we eliminate subsidiaries of listed firms from our sample. The variables and the specifications are the same as those in Table $2 .{ }^{* *},{ }^{* *}$, and * indicate statistical significance at the 1, 5, and $10 \%$ level, respectively.

Dependent variable: BANKRUPTCY (dummy for bankruptcy during the 20 months period after the earthquake)

\begin{tabular}{|c|c|c|c|c|c|c|c|c|}
\hline & \multicolumn{2}{|c|}{$\begin{array}{c}(1) \\
\text { B_DAMAGED } \\
= \\
\text { B_HQDAMAGED }\end{array}$} & \multicolumn{2}{|c|}{$\begin{array}{c}(2) \\
\text { B_DAMAGED } \\
= \\
\text { B_BRDAMAGED }\end{array}$} & \multicolumn{2}{|c|}{$\begin{array}{c}\text { (3) } \\
\text { B_DAMAGED } \\
= \\
\text { B_HQDAMAGED }\end{array}$} & \multicolumn{2}{|c|}{$\begin{array}{c}(4) \\
\text { B_DAMAGED } \\
= \\
\text { B_BRDAMAGED }\end{array}$} \\
\hline & $\mathrm{dF} / \mathrm{dx}$ & p-value & $\mathrm{dF} / \mathrm{dx}$ & p-value & $\mathrm{dF} / \mathrm{dx}$ & p-value & $\mathrm{dF} / \mathrm{dx}$ & p-value \\
\hline B_DAMAGED $\dagger$ & -0.00182 & $0.00 * * *$ & -0.00437 & $0.00 * * *$ & -0.00500 & $0.02 * *$ & -0.02006 & $0.00 * * *$ \\
\hline F_SCORE & -0.00042 & $0.00 * * *$ & -0.00042 & $0.00 * * *$ & -0.00044 & $0.00 * * *$ & -0.00048 & $0.00 * * *$ \\
\hline F_SCORE $\times$ B_DAMAGED $\dagger$ & & & & & 0.00015 & $0.08 *$ & 0.00037 & $0.02 * *$ \\
\hline F_EMP & 0.00000 & $0.09 *$ & 0.00000 & $0.08 *$ & 0.00000 & $0.10 *$ & 0.00000 & $0.10 *$ \\
\hline F_AGE & 0.00002 & $0.05 * *$ & 0.00002 & $0.05 * *$ & 0.00002 & $0.04 * *$ & 0.00002 & $0.04 * *$ \\
\hline F_NBANK & 0.00110 & $0.00 * * *$ & 0.00109 & $0.00 * * *$ & 0.00110 & $0.00 * * *$ & 0.00109 & $0.00 * * *$ \\
\hline F_LISTED & 0.01179 & 0.18 & 0.01238 & 0.16 & 0.00000 & 0.00 & 0.00000 & 0.00 \\
\hline B_REGIONAL & 0.15945 & $0.00 * * *$ & 0.16433 & $0.00 * * *$ & 0.15547 & $0.00 * * *$ & 0.16560 & $0.00 * * *$ \\
\hline B_REGIONAL2 & 0.96116 & $0.00 * * *$ & 0.96594 & $0.00 * * *$ & 0.95731 & $0.00 * * *$ & 0.96683 & $0.00 * * *$ \\
\hline B_SHINKIN & 0.95387 & $0.00 * * *$ & 0.95204 & $0.00 * * *$ & 0.94998 & $0.00 * * *$ & 0.95316 & $0.00 * * *$ \\
\hline B_ROA & -0.29551 & $0.03 * *$ & -0.25471 & $0.07 *$ & -0.30128 & $0.03 * *$ & -0.26564 & $0.06 *$ \\
\hline B_CAP & -0.06749 & $0.00 * * *$ & -0.06066 & $0.00 * * *$ & -0.06803 & $0.00 * * *$ & -0.06095 & $0.00 * * *$ \\
\hline B_LNASSETS & 0.00055 & 0.27 & 0.00045 & 0.30 & 0.00057 & 0.24 & 0.00048 & 0.28 \\
\hline Industry dummies & yes & & yes & & yes & & yes & \\
\hline Obs & 53642 & & 53642 & & 53642 & & 53642 & \\
\hline Pseudo R-squared & 0.0707 & & 0.072 & & 0.0715 & & 0.0733 & \\
\hline Log likelihood & -1607.3533 & & -1605.2418 & & -1606.0482 & & -1602.9230 & \\
\hline
\end{tabular}

† The B_DAMAGED variable is either B_HQDAMAGED or B_BRDAMAGED as indicated in the column heading. 
Table 5 Probit Estimation for Bankruptcy Probability (Controlling for Single Bank Effect)

This table reports the results for our analysis on the probability of bankruptcy when we add a dummy variable indicating that the firm transacts with a single bank (F_B1) and its interaction with F_SCORE to the specifications in Table $2 .{ }^{* * *},{ }^{* *}$, and $*$ indicate statistical significance at the 1,5 , and $10 \%$ level, respectively.

Dependent variable: BANKRUPTCY (dummy for bankruptcy during the 20 months period after the earthquake)

\begin{tabular}{|c|c|c|c|c|c|c|c|c|}
\hline & \multicolumn{2}{|c|}{$\begin{array}{c}(1) \\
\text { B_DAMAGED } \\
= \\
\text { B_HQDAMAGED }\end{array}$} & \multicolumn{2}{|c|}{$\begin{array}{c}(2) \\
\text { B_DAMAGED } \\
= \\
\text { B_BRDAMAGED }\end{array}$} & \multicolumn{2}{|c|}{$\begin{array}{c}(3) \\
\text { B_DAMAGED } \\
= \\
\text { B_HQDAMAGED }\end{array}$} & \multicolumn{2}{|c|}{$\begin{array}{c}(4) \\
\text { B_DAMAGED } \\
= \\
\text { B_BRDAMAGED }\end{array}$} \\
\hline & $\mathrm{dF} / \mathrm{dx}$ & p-value & $\mathrm{dF} / \mathrm{dx}$ & p-value & $\mathrm{dF} / \mathrm{dx}$ & p-value & $\mathrm{dF} / \mathrm{dx}$ & p-value \\
\hline B_DAMAGED † & -0.00174 & $0.00 * * *$ & -0.00415 & $0.00 * * *$ & -0.00470 & $0.02 * *$ & -0.01960 & $0.00 * * *$ \\
\hline F_SCORE & -0.00040 & $0.00 * * *$ & -0.00040 & $0.00 * * *$ & -0.00042 & $0.00 * * *$ & -0.00047 & $0.00 * * *$ \\
\hline F_SCORE $\times$ B_DAMAGED $\dagger$ & & & & & 0.00014 & $0.09 *$ & 0.00035 & $0.02 * *$ \\
\hline F_B1 & -0.00107 & 0.72 & -0.00092 & 0.76 & -0.00101 & 0.74 & -0.00080 & 0.79 \\
\hline F_B1×F_SCORE & 0.00003 & 0.71 & 0.00002 & 0.74 & 0.00002 & 0.75 & 0.00002 & 0.83 \\
\hline F_B1×F_SCORE×B_DAMAGED & & & & & 0.00001 & 0.78 & 0.00002 & 0.64 \\
\hline F_EMP & 0.00001 & $0.02 * *$ & 0.00001 & $0.02 * *$ & 0.00001 & $0.02 * *$ & 0.00001 & $0.02 * *$ \\
\hline F_AGE & 0.00002 & $0.05 * *$ & 0.00002 & $0.05 *$ & 0.00002 & $0.05 * *$ & 0.00002 & $0.05 * *$ \\
\hline F_NBANK & 0.00105 & $0.00 * * *$ & 0.00105 & $0.00 * * *$ & 0.00105 & $0.00 * * *$ & 0.00105 & $0.00 * * *$ \\
\hline B_REGIONAL & 0.29354 & $0.00 * * *$ & 0.29707 & $0.00 * * *$ & 0.28116 & $0.00 * * *$ & 0.26413 & $0.00 * * *$ \\
\hline B_REGIONAL2 & 0.99838 & $0.00 * * *$ & 0.99854 & $0.00 * * *$ & 0.99782 & $0.00 * * *$ & 0.99681 & $0.00 * * *$ \\
\hline B_SHINKIN & 0.99766 & $0.00 * * *$ & 0.99731 & $0.00 * * *$ & 0.99692 & $0.00 * * *$ & 0.99440 & $0.00 * * *$ \\
\hline B_ROA & -0.27685 & $0.03 * *$ & -0.23887 & $0.08 *$ & -0.28284 & $0.03 * *$ & -0.25074 & $0.07 *$ \\
\hline B_CAP & -0.06224 & $0.00 * * *$ & -0.05568 & $0.01 * * *$ & -0.06297 & $0.00 * * *$ & -0.05671 & $0.01 * * *$ \\
\hline B_LNASSETS & 0.00053 & 0.25 & 0.00044 & 0.29 & 0.00056 & 0.23 & 0.00046 & 0.27 \\
\hline Industry dummies & yes & & yes & & yes & & yes & \\
\hline Obs & 53904 & & 53904 & & 53904 & & 53904 & \\
\hline Pseudo R-squared & 0.0704 & & 0.0715 & & 0.0729 & & 0.0711 & \\
\hline Log likelihood & -1619.0610 & & -1605.2418 & & -1614.6174 & & -1617.8177 & \\
\hline
\end{tabular}

† The B_DAMAGED variable is either B_HQDAMAGED or B_BRDAMAGED as indicated in the column heading. 
Table 6 Probit Estimation for Bankruptcy Probability (Alternative definition of F_SCORE)

This table reports the results for our analysis on the probability of bankruptcy when we change the definition of F_SCORE to eliminate the effect of leverage (i.e., F_SCORE_ALT). The other variables and the specifications are the same as those in Table $2 . * * *$, **, and $*$ indicate statistical significance at the 1 , 5 , and $10 \%$ level, respectively.

Dependent variable: BANKRUPTCY (dummy for bankruptcy during the 20 months period after the earthquake)

\begin{tabular}{|c|c|c|c|c|c|c|c|c|}
\hline & \multicolumn{2}{|c|}{$\begin{array}{c}(1) \\
\text { B_DAMAGED } \\
= \\
\text { B_HQDAMAGED }\end{array}$} & \multicolumn{2}{|c|}{$\begin{array}{c}(2) \\
\text { B_DAMAGED } \\
= \\
\text { B_BRDAMAGED }\end{array}$} & \multicolumn{2}{|c|}{$\begin{array}{c}(3) \\
\text { B_DAMAGED } \\
= \\
\text { B_HQDAMAGED }\end{array}$} & \multicolumn{2}{|c|}{$\begin{array}{c}(4) \\
\text { B_DAMAGED } \\
= \\
\text { B_BRDAMAGED }\end{array}$} \\
\hline & $\mathrm{dF} / \mathrm{dx}$ & p-value & $\mathrm{dF} / \mathrm{dx}$ & p-value & $\mathrm{dF} / \mathrm{dx}$ & p-value & $\mathrm{dF} / \mathrm{dx}$ & p-value \\
\hline B_DAMAGED $†$ & -0.00406 & $0.03 * *$ & -0.01146 & $0.00 * * *$ & -0.00770 & $0.01 * *$ & -0.03678 & $0.00 * * *$ \\
\hline F_SCORE_ALT & -0.00036 & $0.00 * * *$ & -0.00036 & $0.00 * * *$ & -0.00038 & $0.00 * * *$ & -0.00046 & $0.00 * * *$ \\
\hline F_SCORE_ALT $\times$ B_DAMAGED $\dagger$ & & & & & 0.00017 & 0.11 & 0.00064 & $0.03 * *$ \\
\hline F_EMP & -0.00004 & $0.09 *$ & -0.00004 & $0.09 *$ & -0.00004 & $0.10 *$ & -0.00004 & 0.10 \\
\hline F_AGE & 0.00004 & 0.33 & 0.00004 & 0.34 & 0.00004 & 0.34 & 0.00004 & 0.33 \\
\hline F_NBANK & 0.00236 & $0.00 * * *$ & 0.00234 & $0.00 * * *$ & 0.00235 & $0.00 * * *$ & 0.00230 & $0.00 * * *$ \\
\hline B_REGIONAL & 0.01534 & $0.03 * *$ & 0.01631 & $0.01 * *$ & 0.01546 & $0.03 * *$ & 0.01660 & $0.01 * *$ \\
\hline B_REGIONAL2 & 0.06228 & $0.03 * *$ & 0.07517 & $0.01 * *$ & 0.06340 & $0.03 * *$ & 0.07870 & $0.01 * *$ \\
\hline B_SHINKIN & 0.13017 & $0.01 * *$ & 0.13332 & $0.01 * * *$ & 0.13300 & $0.01 * *$ & 0.14021 & $0.01 * * *$ \\
\hline B_ROA & -0.38581 & 0.47 & -0.23366 & 0.69 & -0.38808 & 0.47 & -0.23796 & 0.68 \\
\hline B_CAP & -0.14336 & $0.05 *$ & -0.13225 & $0.06 *$ & -0.14291 & $0.05 *$ & -0.13144 & $0.06 *$ \\
\hline B_LNASSETS & 0.00282 & $0.07 *$ & 0.00284 & $0.04 * *$ & 0.00287 & $0.06 *$ & 0.00293 & $0.03 * *$ \\
\hline Industry dummies & yes & & yes & & yes & & yes & \\
\hline Obs & 14076 & & 14076 & & 14076 & & 14076 & \\
\hline Pseudo R-squared & 0.0461 & & 0.0492 & & 0.0467 & & 0.0511 & \\
\hline Log likelihood & -695.3964 & & -693.1461 & & -694.9928 & & -691.7697 & \\
\hline
\end{tabular}

† The B_DAMAGED variable is either B_HQDAMAGED or B_BRDAMAGED as indicated in the column heading. 
Table 7 Capital Injection, Bank Damage, and the Bankruptcy Probability

This table reports the breakdown of our sample firms depending on whether their main banks obtained public capital injection and on whether they are damaged (proxied by

B_HQDAMAGED). The first row reports the whole sample results, and the second and the third rows respectively report the results for the firms that did not, and did go bankrupt (after the capital injection to their main banks).

\begin{tabular}{|c|c|c|c|c|c|c|c|c|c|c|c|c|}
\hline & \multicolumn{5}{|c|}{ Without capital injection to main banks } & \multicolumn{5}{|c|}{ With capital injection to main banks } & \multirow{2}{*}{\multicolumn{2}{|c|}{ Total }} \\
\hline & \multicolumn{2}{|c|}{ B_HQDAMAGED $=0$} & \multicolumn{2}{|c|}{ B_HQDAMAGED $=1$} & \multirow{2}{*}{$\begin{array}{l}\text { Total } \\
\text { Obs }\end{array}$} & \multicolumn{2}{|c|}{ B_HQDAMAGED $=0$} & \multicolumn{2}{|c|}{ B_HQDAMAGED = 1} & \multirow{2}{*}{$\begin{array}{c}\text { Total } \\
\text { Obs }\end{array}$} & & \\
\hline & Obs & $\%$ & Obs & $\%$ & & Obs & $\%$ & Obs & $\%$ & & Obs & $\%$ \\
\hline Total & 41,745 & $100.00 \%$ & 6,927 & $100.00 \%$ & 48,672 & 1,840 & $100.00 \%$ & 3,392 & $100.00 \%$ & 5,232 & 53,904 & $100.00 \%$ \\
\hline BANKRUPTCY $=0$ & 41,508 & $99.43 \%$ & 6,901 & $99.62 \%$ & 48,409 & 1,835 & $99.73 \%$ & 3,382 & $99.71 \%$ & 5,217 & 53,626 & $99.48 \%$ \\
\hline BANKRUPTCY $=1$ & 237 & $0.57 \%$ & 26 & $0.38 \%$ & 263 & 5 & $0.27 \%$ & 10 & $0.29 \%$ & 15 & 278 & $0.52 \%$ \\
\hline
\end{tabular}




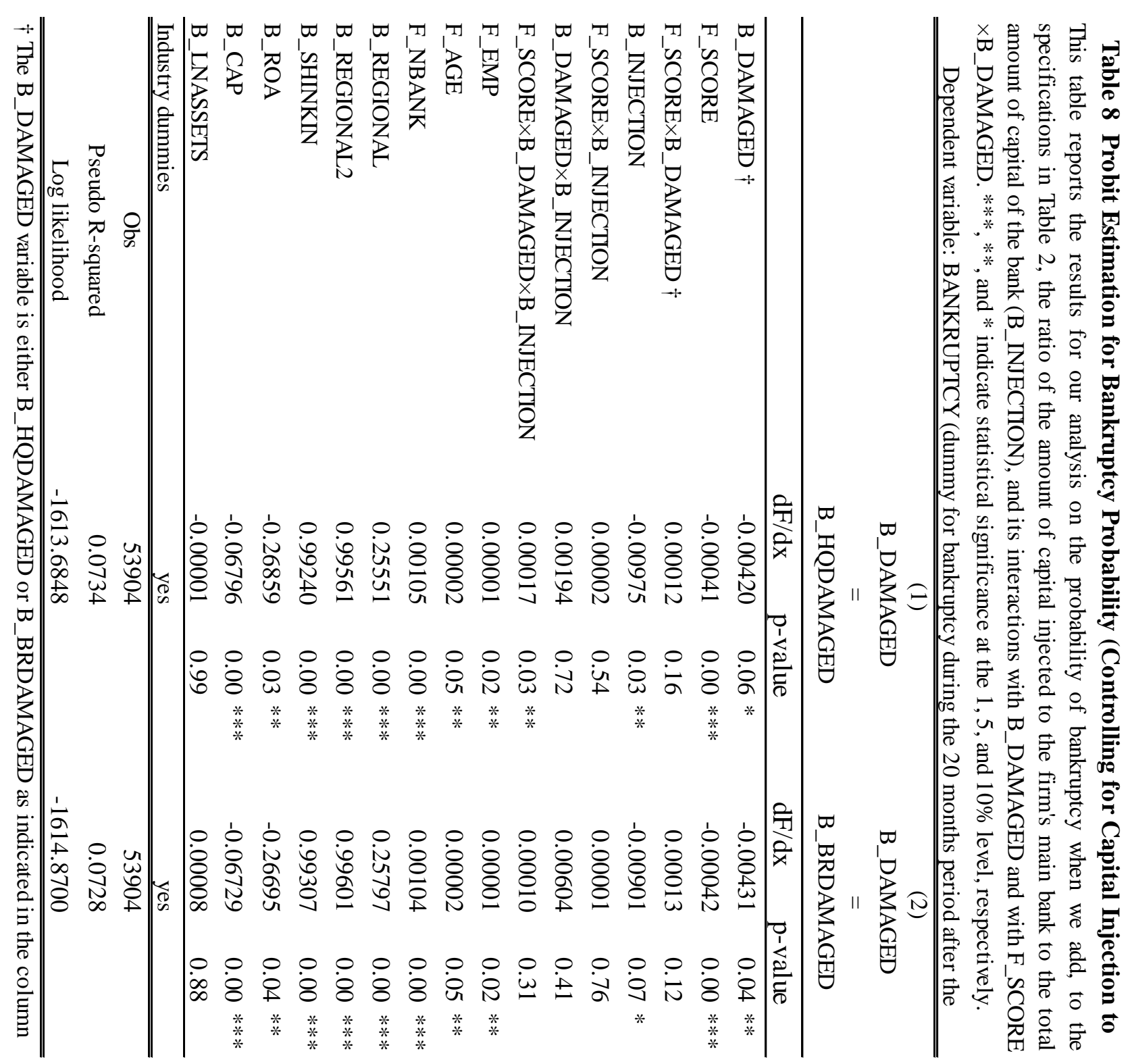




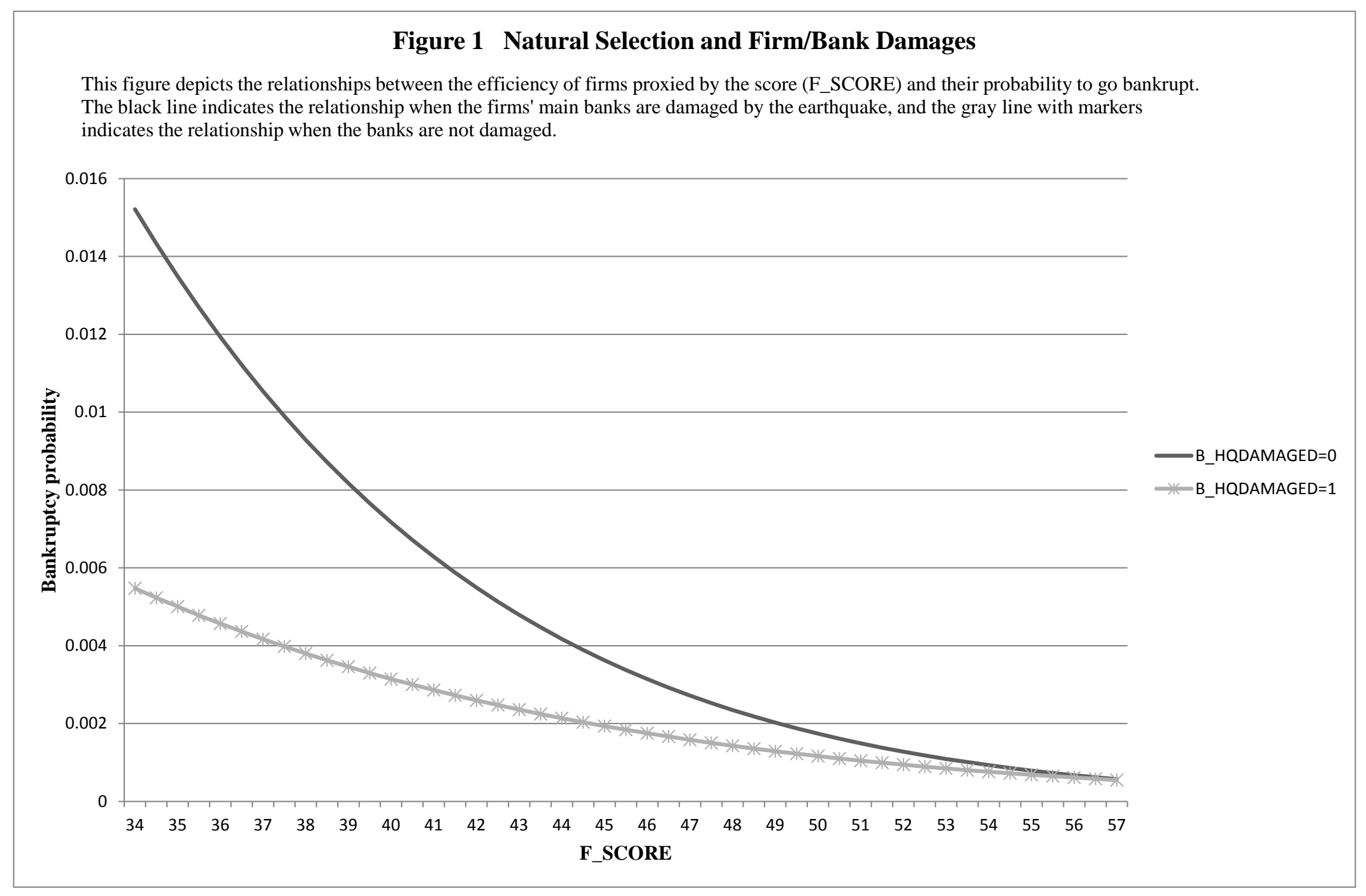

